\title{
Neoplastic Plasma Cells More than 20 Percent of Bone Marrow Nucleated Cells
}

National Cancer Institute

\section{Source}

National Cancer Institute. Neoplastic Plasma Cells More than 20 Percent of Bone

Marrow Nucleated Cells. NCI Thesaurus. Code C138322.

A semi-quantitative microscopic finding indicating that more than 20 percent of the nucleated cells in a bone marrow sample are neoplastic plasma cells. 